\title{
Dropperful Dosing Unit
}

National Cancer Institute

\section{Source}

National Cancer Institute. Dropperful Dosing Unit. NCI Thesaurus. Code C122631.

A dosing unit equal to the amount of active ingredient(s) contained in a dropperful. 